4

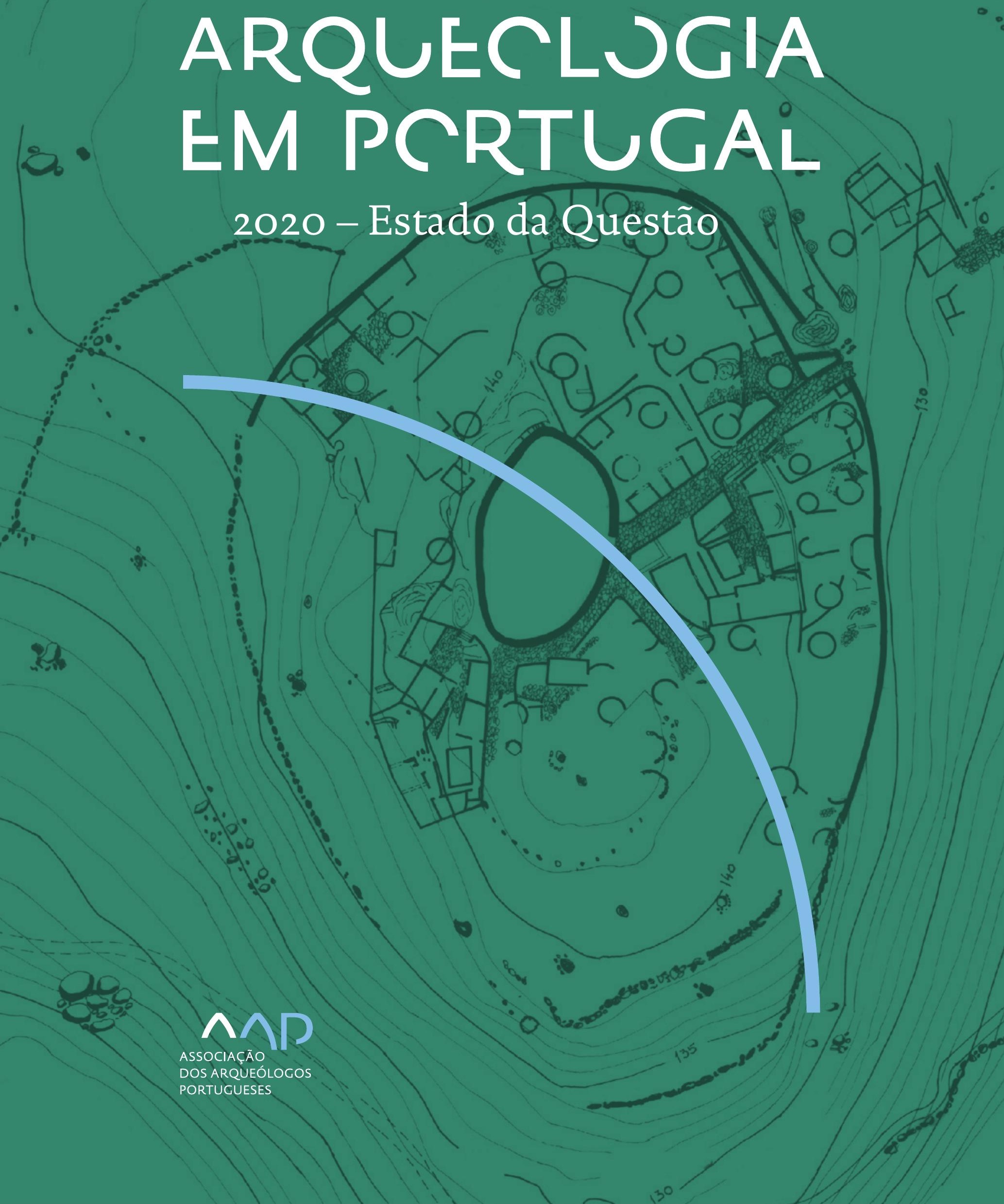


Coordenação editorial: José Morais Arnaud, César Neves e Andrea Martins Design gráfico: Flatland Design

AAP - ISBN: 978-972-9451-89-8

CITCEM - ISBN: 978-989-8970-25-1

Associação dos Arqueólogos Portugueses e CITCEM

Lisboa, 2020

O conteúdo dos artigos é da inteira responsabilidade dos autores. Sendo assim a Associação dos Arqueólogos Portugueses declina qualquer responsabilidade por eventuais equívocos ou questões de ordem ética e legal.

Desenho de capa:

Planta do castro de Monte Mozinho (Museu Municipal de Penafiel).

\section{$\hat{\wedge} \mathrm{P}$}

DOS ARQUEÓLOGOS PORTUGUESES

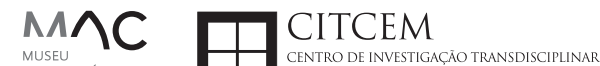
MUSEU
ARQUELLÓGICO
DO CARMO
U.PORTO

FLUP FACULDADE DE LETRAS
UNIVERSIDADE DO PORTO

Apoio

EC para a Ciência 


\section{Índice}

15 Prefácio

José Morais Arnaud

\section{Historiografia e Teoria}

17 Território, comunidade, memória e emoção: a contribuição da história da arqueologia (algumas primeiras e breves reflexões)

Ana Cristina Martins

25 Como descolonizar a arqueologia portuguesa?

Rui Gomes Coelho

41 Arqueologia e Modernidade: uma revisitação pessoal e breve de alguns aspetos da obra homónima de Julian Thomas de 2004

Vítor Oliveira Jorge

57 Dados para a História das Mulheres na Arqueologia portuguesa, dos finais do século XIX aos inícios do século XX: números, nomes e tabelas

Filipa Dimas / Mariana Diniz

73 Retractos da arqueologia portuguesa na imprensa: (in)visibilidades no feminino

Catarina Costeira / Elsa Luís

85 Arqueologia e Arqueólogos no Norte de Portugal Jacinta Bugalhão

101 Vieira Guimarães (1864-1939) e a arqueologia em Tomar: uma abordagem sobre o território e as gentes

João Amendoeira Peixoto / Ana Cristina Martins

115 Os memoráveis? A arqueologia algarvia na imprensa nacional e regional na presente centúria (2001-2019): características, visões do(s) passado(s) e a arqueologia

enquanto marca

Frederico Agosto / João Silva

129 A Evolução da Arqueologia Urbana e a Valorização Patrimonial no Barlavento Algarvio: Os casos de Portimão e Silves

Artur Mateus / Diogo Varandas / Rafael Boavida

\section{Gestão, Valorização e Salvaguarda do Património}

145 O Caderno Reivindicativo e as condições de trabalho em Arqueologia Miguel Rocha / Liliana Matias Carvalho / Regis Barbosa / Mauro Correia / Sara Simões / Jacinta Bugalhão / Sara Brito / Liliana Veríssimo Carvalho / Richard Peace / Pedro Peça / Cézer Santos

155 Os Estudos de Impacte Patrimonial como elemento para uma estratégia sustentável de minimização de impactes no âmbito de reconversões agrícolas Tiago do Pereiro

165 Salvaguarda de Património arqueológico em operações florestais: gestão e sensibilização Filipa Bragança / Gertrudes Zambujo / Sandra Lourenço / Belém Paiva / Carlos Banha / Frederico Tatá Regala / Helena Moura / Jacinta Bugalhão / João Marques / José Correia / Pedro Faria / Samuel Melro

179 Os valores do Património: uma investigação sobre os Sítios Pré-históricos de Arte Rupestre do Vale do Rio Côa e de Siega Verde José Paulo Francisco 
189 Conjugando recursos arqueológicos e naturais para potenciar as visitas ao Geoparque Litoral de Viana do Castelo (Noroeste de Portugal)

Hugo A. Sampaio / Ana M.S. Bettencourt / Susana Marinho / Ricardo Carvalhido

203 Áreas de Potencial Arqueológico na Região do Médio Tejo: Modelo Espacial Preditivo Rita Ferreira Anastácio / Ana Filipa Martins / Luiz Oosterbeek

223 Património Arqueológico e Gestão Territorial: O contributo da Arqueologia para a revisão do PDM de Avis

Ana Cristina Ribeiro

237 A coleção arqueológica do extinto Museu Municipal do Porto - Origens, Percursos e Estudos

Sónia Couto

251 Valpaços - uma nova carta arqueológica

Pedro Pereira / Maria de Fátima Casares Machado

263 Arqueologia na Cidade de Peniche

Adriano Constantino / Luís Rendeiro

273 Arqueologia Urbana: a cidade de Lagos como caso de Estudo Cátia Neto

285 Estratégias de promoção do património cultural subaquático nos Açores. O caso da ilha do Faial

José Luís Neto / José Bettencourt / Luís Borges / Pedro Parreira

297 Carta Arqueológica da Cidade Velha: Uma primeira abordagem

Jaylson Monteiro / Nireide Tavares / Sara da Veiga / Claudino Ramos / Edson Brito /

Carlos Carvalho / Francisco Moreira / Adalberto Tavares

311 Antropologia Virtual: novas metodologias para a análise morfológica e funcional Ricardo Miguel Godinho / Célia Gonçalves

\section{Didáctica da Arqueologia}

327 Como os projetos de Arqueologia podem contribuir para uma comunidade culturalmente mais consciente Alexandra Figueiredo / Claúdio Monteiro / Adolfo Silveira / Ricardo Lopes

337 Educação Patrimonial - Um cidadão esclarecido é um cidadão ativo! Ana Paula Almeida

351 A aproximação da Arqueologia à sala de aula: um caso de estudo no $3^{\circ}$ ciclo do Ensino Básico Luís Serrão Gil

363 Arqueologia 3.o - Pensar e comunicar a Arqueologia para um futuro sustentável Mónica Rolo

377 “Conversa de Arqueólogos" - Divulgar a Arqueologia em tempos de Pandemia Diogo Teixeira Dias

389 Escola Profissional de Arqueologia: desafios e oportunidades Susana Nunes / Dulcineia Pinto / Júlia Silva / Ana Mascarenhas

399 Os Museus de Arqueologia e os Jovens: a oferta educativa para o público adolescente Beatriz Correia Barata / Leonor Medeiros

411 O museu universitário como mediador entre a ciência e a sociedade: o exemplo da secção de arqueologia no Museu de História Natural e da Ciência da Universidade do Porto (MHNC-UP)

Rita Gaspar 
421 Museu de Lanifícios: Real Fábrica de Panos. Atividades no âmbito da Arqueologia Beatriz Correia Barata / Rita Salvado

427 Arqueologia Pública e o caso da localidade da Mata (Torres Novas) Cláudia Manso / Ana Rita Ferreira / Cristiana Ferreira / Vanessa Cardoso Antunes

431 Do sítio arqueológico ao museu: um percurso (também) didático Lídia Fernandes

447 Estão todos convidados para a Festa! E para dançar também... O projecto do Serviço Educativo do Museu Arqueológico do Carmo na $5^{\underline{a}}$ Edição da Festa da Arqueologia Rita Pires dos Santos

459 O “Clã de Carenque”, um projeto didático de arqueologia Eduardo Gonzalez Rocha

469 Mediação cultural: peixe que puxa carroça nas Ruínas Romanas de Troia Inês Vaz Pinto / Ana Patrícia Magalhães / Patrícia Brum / Filipa Santos

481 Didática Arqueológica, experiências do Projeto Mértola Vila Museu Maria de Fátima Palma / Clara Rodrigues / Susana Gómez / Lígia Rafael

\section{Arte Rupestre}

497 Os inventários de arte rupestre em Portugal Mila Simões de Abreu

513 O projeto FIRST-ART - conservação, documentação e gestão das primeiras manifestações de arte rupestre no Sudoeste da Península Ibérica: as grutas do Escoural e Maltravieso Sara Garcês / Hipólito Collado / José Julio García Arranz / Luiz Oosterbeek / António Carlos Silva / Pierluigi Rosina / Hugo Gomes / Anabela Borralheiro Pereira / George Nash / Esmeralda Gomes / Nelson Almeida / Carlos Carpetudo

523 Trabalhos de documentação de arte paleolítica realizados no âmbito do projeto PalæoCôa André Tomás Santos / António Fernando Barbosa / Luís Luís / Marcelo Silvestre / Thierry Aubry

537 Imagens fantasmagóricas, silhuetas elusivas: as figuras humanas na arte do Paleolítico Superior da região do Côa Mário Reis

$55^{1}$ Os motivos zoomórficos representados nas placas de tear de Vila Nova de São Pedro (Azambuja, Portugal) Andrea Martins / César Neves / José M. Arnaud / Mariana Diniz

571 Arte Rupestre do Monte de Góios (Lanhelas, Caminha). Síntese dos resultados dos trabalhos efectuados em 2007-2009 Mário Varela Gomes

599 Gravuras rupestres de barquiformes no Monte de S. Romão, Guimarães, Noroeste de Portugal Daniela Cardoso

613 Círculos segmentados gravados na Bacia do Rio Lima (Noroeste de Portugal): contributos para o seu estudo Diogo Marinho / Ana M.S. Bettencourt / Hugo Aluai Sampaio

631 Equídeos gravados no curso inferior do Rio Mouro, Monção (NW Portugal). Análise preliminar Coutinho, L.M. / Bettencourt, A.M.S / Sampaio, Hugo A.S

645 Paletas na Arte Rupestre do Noroeste de Portugal. Inventário preliminar Bruna Sousa Afonso / Ana M. S. Bettencourt / Hugo A. Sampaio 


\section{Pré-História}

661 O projeto Miño/Minho: balanço de quatro anos de trabalhos arqueológicos Sérgio Monteiro-Rodrigues / João Pedro Cunha-Ribeiro / Eduardo Méndez-Quintas / Carlos Ferreira / Pedro Xavier / José Meireles / Alberto Gomes / Manuel Santonja / Alfredo Pérez-González

677 A ocupação paleolítica da margem esquerda do Baixo Minho: a indústria lítica do sítio de Pedreiras 2 (Monção, Portugal) e a sua integração no contexto regional Carlos Ferreira / João Pedro Cunha-Ribeiro / Sérgio Monteiro-Rodrigues / Eduardo Méndez-Quintas / Pedro Xavier / José Meireles / Alberto Gomes / Manuel Santonja / Alfredo Pérez-González

693 O sítio acheulense do Plistocénico médio da Gruta da Aroeira Joan Daura / Montserrat Sanz / Filipa Rodrigues / Pedro Souto / João Zilhão

703 As sociedades neandertais no Barlavento algarvio: modelos preditivos com recurso aos SIG

Daniela Maio

715 A utilização de quartzo durante o Paleolítico Superior no território dos vales dos rios Vouga e Côa

Cristina Gameiro / Thierry Aubry / Bárbara Costa / Sérgio Gomes / Luís Luís / Carmen Manzano / André Tomás Santos

733 Uma perspetiva diacrónica da ocupação do concheiro do Cabeço da Amoreira (Muge, Portugal) a partir da tecnologia lítica Joana Belmiro / João Cascalheira / Célia Gonçalves

745 Novos dados sobre a Pré-história Antiga no concelho de Palmela. A intervenção arqueológica no sítio do Poceirão I

Michelle Teixeira Santos

757 Problemas em torno de Datas Absolutas Pré-Históricas no Norte do Alentejo Jorge de Oliveira

771 Povoamento pré-histórico nas áreas montanhosas do NO de Portugal: o Abrigo 1 de Vale de Cerdeira Pedro Xavier / José Meireles / Carlos Alves

783 Apreciação do povoamento do Neolítico Inicial na Baixa Bacia do Douro. A Lavra I (Serra da Aboboreira) como caso de estudo Maria de Jesus Sanches

797 O Processo de Neolitização na Plataforma do Mondego: os dados do Sector C do Outeiro dos Castelos de Beijós (Carregal do Sal)

João Carlos de Senna-Martinez / José Manuel Quintã Ventura / Andreia Carvalho / Cíntia Maurício

823 Novos trabalhos na Lapa da Bugalheira (Almonda, Torres Novas) Filipa Rodrigues / Pedro Souto / Artur Ferreira / Alexandre Varanda / Luís Gomes / Helena Gomes / João Zilhão

837 A pedra polida e afeiçoada do sítio do Neolítico médio da Moita do Ourives (Benavente, Portugal)

César Neves

857 Casal do Outeiro (Encarnação, Mafra): novos contributos para o conhecimento do povoamento do Neolítico final na Península de Lisboa.

Cátia Delicado / Carlos Maneira e Costa / Marta Miranda / Ana Catarina Sousa

873 Stresse infantil, morbilidade e mortalidade no sítio arqueológico do Neolítico Final/ Calcolítico ( $4^{\circ}$ e $3^{\circ}$ milénio a.C.) do Monte do Carrascal 2 (Ferreira do Alentejo, Beja) Liliana Matias de Carvalho / Sofia N. Wasterlain 
885 Come together: O Conjunto Megalítico das Motas (Monção, Viana do Castelo) e as expressões Campaniformes do Alto Minho Ana Catarina Basílio / Rui Ramos

899 Trabalhos arqueológicos no sítio Calcolítico da Pedreira do Poio Carla Magalhães / João Muralha / Mário Reis / António Batarda Fernandes

913 O sítio arqueológico de Castanheiro do Vento. Da arquitectura do sítio à arquitectura de um território João Muralha Cardoso

925 Estudo zooarqueológico das faunas do Calcolítico final de Vila Nova de São Pedro (Azambuja, Portugal): Campanhas de 2017 e 2018 Cleia Detry / Ana Catarina Francisco / Mariana Diniz / Andrea Martins / César Neves / José Morais Arnaud

943 As faunas depositadas no Museu Arqueológico do Carmo provenientes de Vila Nova de São Pedro (Azambuja): as campanhas de 1937 a 1967 Ana Catarina Francisco / Cleia Detry / César Neves / Andrea Martins / Mariana Diniz / José Morais Arnaud

959 Análise funcional de material lítico em sílex do castro de Vila Nova de S. Pedro (Azambuja, Portugal): uma primeira abordagem Rafael Lima

971 O recinto da Folha do Ouro 1 (Serpa) no contexto dos recintos de fossos calcolíticos alentejanos

António Carlos Valera / Tiago do Pereiro / Pedro Valério / António M. Monge Soares

\section{Proto-História}

987 Produção de sal marinho na Idade do Bronze do noroeste Português. Alguns dados para uma reflexão

Ana M. S. Bettencourt / Sara Luz / Nuno Oliveira / Pedro P. Simões / Maria Isabel C. Alves / Emílio Abad-Vidal

1001 A estátua-menir do Pedrão ou de São Bartolomeu do Mar (Esposende, noroeste de Portugal) no contexto arqueológico da fachada costeira de entre os rios Neiva e Cávado Ana M. S. Bettencourt / Manuel Santos-Estévez / Pedro Pimenta Simões / Luís Gonçalves

1015 O Castro do Muro (Vandoma/Baltar, Paredes) - notas para uma biografia de ocupação da Idade do Bronze à Idade Média

Maria Antónia D. Silva / Ana M. S. Bettencourt / António Manuel S. P. Silva / Natália Félix

1031 Do Bronze Final à Idade Média - continuidades e hiatos na ocupação de Povoados em Oliveira de Azeméis João Tiago Tavares / Adriaan de Man

1041 As faunas do final da Idade do Bronze no Sul de Portugal: leituras desde o Outeiro do Circo (Beja)

Nelson J. Almeida / Íris Dias / Cleia Detry / Eduardo Porfírio / Miguel Serra

1055 A Espada do Monte das Oliveiras (Serpa) - uma arma do Bronze Pleno do Sudoeste Rui M. G. Monge Soares / Pedro Valério / Mariana Nabais / António M. Monge Soares

1065 São Julião da Branca (Albergaria-a-Velha) - Investigação e valorização de um povoado do Bronze Final

António Manuel S. P. Silva / Paulo A. P. Lemos / Sara Almeida e Silva / Edite Martins de Sá

1083 Do castro de S. João ao Mosteiro de Santa Clara: notícia de uma intervenção arqueológica, em Vila do Conde Rui Pinheiro 
1095 O castro de Ovil (Espinho), um quarto de século de investigação - resultados e questões em aberto

Jorge Fernando Salvador / António Manuel S. P. Silva

1111 O Castro de Salreu (Estarreja), um povoado proto-histórico no litoral do Entre Douro e Vouga

Sara Almeida e Silva / António Manuel S. P. Silva / Paulo A. P. Lemos / Edite Martins de Sá

1127 Castro de Nossa Senhora das Necessidades (Sernancelhe): uma primeira análise artefactual Telma Susana O. Ribeiro

${ }_{1141}$ A cividade de Bagunte. O estado atual da investigação Pedro Brochado de Almeida

1153 Zoomorfos na cerâmica da Idade do Ferro no NW Peninsular: inventário, cronologias e significado Nuno Oliveira / Cristina Seoane

1163 Vasos gregos em Portugal: diferentes maneiras de contar a história do intercâmbio cultural na Idade do Ferro

Daniela Ferreira

1175 Os exotica da necrópole da Idade do Ferro do Olival do Senhor dos Mártires (Alcácer do Sal) no seu contexto regional

Francisco B. Gomes

\section{Antiguidade Clássica e Tardia}

1191 O uso de madeira como combustível no sítio da Quinta de Crestelos (Baixo Sabor): da Idade do Ferro à Romanização Filipe Vaz / João Tereso / Sérgio Simões Pereira / José Sastre / Javier Larrazabal Galarza / Susana Cosme / José António Pereira / Israel Espi

1207 Cultivos de Época Romana no Baixo Sabor: continuidade em tempos de mudança? João Pedro Tereso / Sérgio Simões Pereira / Filipe Santos / Luís Seabra / Filipe Vaz

1221 A casa romana na Hispânia: aplicação dos modelos itálicos nas províncias ibéricas Fernanda Magalhães / Diego Machado / Manuela Martins

1235 As pinturas murais romanas da Rua General Sousa Machado, n. ${ }^{5}$ 1, Chaves José Carvalho

1243 Trás do Castelo (Vale de Mir, Pegarinhos, Alijó) - Uma exploração agrícola romana do Douro

Tony Silvino / Pedro Pereira

1255 A sequência de ocupação no quadrante sudeste de Bracara Augusta: as transformações de uma unidade doméstica Lara Fernandes / Manuela Martins

1263 Os Mosaicos com decoração geométrica e geométrico-vegetalista dos sítios arqueológicos da área do Conuentus Bracaraugustanus. Novas abordagens quanto à conservação, restauro, decoração e datação Maria de Fátima Abraços / Licínia Wrench

1277 “Casa Romana” do Castro de São Domingos (Cristelos, Lousada): Escavação, Estudo e Musealização Paulo André de P. Lemos

1291 A arqueobotânica no Castro de Guifões (Matosinhos, Noroeste de Portugal): O primeiro estudo carpológico

Luís Seabra / Andreia Arezes / Catarina Magalhães / José Varela / João Pedro Tereso 
1305 Um Horreum Augustano na Foz do Douro (Monte do Castelo de Gaia, Vila Nova de Gaia) Rui Ramos

1311 Ponderais romanos na Lusitânia: padrões, formas, materiais e contextos de utilização Diego Barrios Rodríguez

1323 Um almofariz centro-itálico na foz do Mondego

Marco Penajoia

1335 Estruturas romanas de Carnide - Lisboa Luísa Batalha / Mário Monteiro / Guilherme Cardoso

1347 O contexto funerário do sector da "necrópole NO" da Rua das Portas de S. Antão (Lisboa): o espaço, os artefactos, os indivíduos e a sua interconectividade na interpretação do passado Sílvia Loja, José Carlos Quaresma, Nelson Cabaço, Marina Lourenço, Sílvia Casimiro, Rodrigo Banha da Silva, Francisca Alves-Cardoso

${ }_{1361}$ Povoamento em época Romana na Amadora - resultados de um projeto pluridisciplinar Gisela Encarnação / Vanessa Dias

1371 A Arquitectura Residencial em Mirobriga (Santiago do Cacém): contributo a partir de um estudo de caso Filipe Sousa / Catarina Felício

${ }_{1385}$ O fim do ciclo. Saneamento e gestão de resíduos nos edifícios termais de Mirobriga (Santiago do Cacém)

Catarina Felício / Filipe Sousa

1399 Balsa, Topografia e Urbanismo de uma Cidade Portuária Vítor Silva Dias / João Pedro Bernardes / Celso Candeias / Cristina Tété Garcia

1413 No Largo das Mouras Velhas em Faro (2017): novas evidências da necrópole norte de Ossonoba e da sua ocupação medieval Ricardo Costeira da Silva / Paulo Botelho / Fernando Santos / Liliana Nunes

1429 Instrumentos de pesca recuperados numa fábrica de salga em Ossonoba (Faro) Inês Rasteiro / Ricardo Costeira da Silva / Paulo Botelho

1439 A Necrópole Romana do Eirô, Duas Igrejas (Penafiel): intervenção arqueológica de 2016 Laura Sousa / Teresa Soeiro

1457 Ritual, descarte ou afetividade? A presença de Canis lupus familiaris na Necrópole Noroeste de Olisipo (Lisboa)

Beatriz Calapez Santos / Sofia Simões Pereira / Rodrigo Banha da Silva / Sílvia Casimiro / Cleia Detry / Francisca Alves Cardoso

1467 Dinâmicas económicas em Bracara na Antiguidade Tardia Diego Machado / Manuela Martins / Fernanda Magalhães / Natália Botica

1479 Cerâmicas e Vidros da Antiguidade Tardia do Edifício sob a Igreja do Bom Jesus (Vila Nova de Gaia) Joaquim Filipe Ramos

1493 Novos contributos para a topografia histórica de Mértola no período romano e na Antiguidade Tardia Virgílio Lopes

\section{8. Época Medieval}

1511 Cerâmicas islâmicas no Garb setentrional "português": algumas evidências e incógnitas Constança dos Santos / Helena Catarino / Susana Gómez / Maria José Gonçalves / Isabel Inácio / Gonçalo Lopes / Jacinta Bugalhão / Sandra Cavaco / Jaquelina Covaneiro / Isabel Cristina Fernandes / Ana Sofia Gomes 
1525 Contributo para o conhecimento da cosmética islâmica, em Silves, durante a Idade Média Rosa Varela Gomes

1537 Yábura e o seu território - uma análise histórico-arqueológica de Évora entre os séculos VIII-XII José Rui Santos

1547 A encosta sul do Castelo de Palmela - resultados preliminares da escavação arqueológica Luís Filipe Pereira / Michelle Teixeira Santos

1559 A igreja de São Lourenço (Mouraria, Lisboa): um conjunto de silos e de cerâmica medieval islâmica

Andreia Filipa Moreira Rodrigues

1571 O registo material de movimentações populacionais no Médio Tejo, durante os séculos XII-XIII. Dois casos de "sunken featured buildings", nos concelhos de Cartaxo e Torres Novas Marco Liberato / Helena Santos / Nuno Santos

1585 O nordeste transmontano nos alvores da Idade média. Notas para reflexão Ana Maria da Costa Oliveira

1601 Sepulturas escavadas na rocha do Norte de Portugal e do Vale do Douro: primeiros resultados do Projecto SER-NPVD

Mário Jorge Barroca / César Guedes / Andreia Arezes / Ana Maria Oliveira

1619 "Portucalem Castrum Novum" entre o Mediterrâneo e o Atlântico: o estudo dos materiais cerâmicos alto-medievais do arqueossítio da rua de D. Hugo, nํ. 5 (Porto) João Luís Veloso

1627 A Alta Idade Média na fronteira de Lafões: notas preliminares sobre a Arqueologia no Concelho de Vouzela

Manuel Luís Real / Catarina Tente

1641 Um conjunto cerâmico medieval fora de portas: um breve testemunho aveirense Susana Temudo

${ }_{1651}$ Os Lóios do Porto: uma perspetiva integrada no panorama funerário da Baixa Idade Média à Época Moderna em meios urbanos em Portugal

Ana Lema Seabra

1659 O Caminho Português Interior de Santiago como eixo viário na Idade Média Pedro Azevedo

1665 Morfologia Urbana: Um exercício em torno do Castelo de Ourém André Donas-Botto / Jaqueline Pereira

1677 Intervenção arqueológica na Rua Marquês de Pombal/Largo do Espírito Santo (Bucelas, Loures)

Florbela Estêvão / Nathalie Antunes-Ferreira / Dário Ramos Neves / Inês Lisboa

1691 O Cemitério Medieval do Poço do Borratém e a espacialidade funerária na cidade de Lisboa Inês Belém / Vanessa Filipe / Vasco Noronha Vieira / Sónia Ferro / Rodrigo Banha da Silva

1705 Um Espaço Funerário Conventual do séc. XV em Lisboa: o caso do Convento de São Domingos da Cidade Sérgio Pedroso / Sílvia Casimiro / Rodrigo Banha da Silva / Francisca Alves Cardoso

\section{9. Época Moderna e Contemporânea}

1721 Arqueologia Moderna em Portugal: algumas reflexões críticas em torno da quantificação de conjuntos cerâmicos e suas inferências históricas e antropológicas Rodrigo Banha da Silva / André Bargão / Sara da Cruz Ferreira

1733 Faianças de dois contextos entre os finais do século XVI e XVIII do Palácio dos Condes de Penafiel, Lisboa

Martim Lopes / Tomás Mesquita 
1747 Um perfil de consumo do século XVIII na foz do Tejo: O caso do Mercado da Ribeira, Lisboa Sara da Cruz Ferreira / Rodrigo Banha da Silva / André Bargão

1761 Os Cachimbos dos Séculos XVII e XVIII do Palácio Mesquitela e Convento dos Inglesinhos (Lisboa)

Inês Simão / Marina Pinto / João Pimenta / Sara da Cruz Ferreira / André Bargão / Rodrigo Banha da Silva

1775 "Tomar os fumos da erua que chamão em Portugal erua sancta». Estudo de Cachimbos provenientes da Rua do Terreiro do Trigo, Lisboa

Miguel Martins de Sousa / José Pedro Henriques / Vanessa Galiza Filipe

1787 Cachimbos de Barro Caulínitico da Sé da Cidade Velha (República de Cabo Verde)

Rodrigo Banha da Silva / João Pimenta / Clementino Amaro

1801 Algumas considerações sobre espólio não cerâmico recuperado no Largo de Jesus (Lisboa) Carlos Boavida

1815 Adereços de vidro, dos séculos XVI-XVIII, procedentes do antigo Convento de Santana de Lisboa (anéis, braceletes e contas)

Joana Gonçalves / Rosa Varela Gomes / Mário Varela Gomes

1837 Da ostentação, luxo e poder à simplicidade do uso quotidiano: arqueologia e simbologia de joias e adornos da Idade Moderna Portuguesa Jéssica Iglésias

1849 Os amuletos em Portugal - dos objetos às superstições: o coral vermelho Alexandra Vieira

1865 Cerâmicas de Vila Franca de Xira nos séculos XV e XVI Eva Pires

1879 «Não passa por teu o que me pertence». Marcas de individualização associadas a faianças do Convento de Nossa Senhora de Aracoeli, Alcácer do Sal Catarina Parreira / Íris Fragoso / Miguel Martins de Sousa

1891 Cerâmica de Leiria: alguns focos de produção

Jaqueline Pereira / André Donas-Botto

1901 Os Fornos na Rua da Biquinha, em Óbidos Hugo Silva / Filipe Oliveira

1909 A casa de Pêro Fernandes, contador dos contos de D. Manuel I: o sítio arqueológico da Silha do Alferes, Seixal (século XVI) Mariana Nunes Ferreira

1921 O Alto da Vigia (Sintra) e a vigilância e defesa da costa Alexandre Gonçalves / Sandra Santos

1937 O contexto da torre sineira da Igreja de Santa Maria de Loures Paulo Calaveira / Martim Lopes

1949 A Necrópole do Hospital Militar do Castelo de São Jorge e as práticas funerárias na Lisboa de Época Moderna Susana Henriques / Liliana Matias de Carvalho / Ana Amarante / Sofia N. Wasterlain

1963 SAND - Sarilhos Grandes Entre dois Mundos: o adro da Igreja e a Paleobiologia dos ossos humanos recuperados

Paula Alves Pereira / Roger Lee Jesus / Bruno M. Magalhães

1975 Expansão urbana da vila de Cascais no século XVII e XVIII: a intervenção arqueológica na Rua da Vitória no 15 a 17

Tiago Pereira / Vanessa Filipe

1987 Novos dados para o conhecimento do Urbanismo de Faro em época Moderna Ana Rosa 
1995 Um exemplo de Arqueologia Urbana em Alcoutim: o Antigo Edifício dos CTT Marco Fernandes / Marta Dias / Alexandra Gradim / Virgílio Lopes / Susana Gómez Martínez

2007 Palácio dos Ferrazes (Rua das Flores/Rua da Vitória, Porto): a cocheira de Domingos Oliveira Maia

Francisco Raimundo

2021 As muitas vidas de um edifício urbano: História, Arqueologia e Antropologia no antigo Recreatório Paroquial de Penafiel Helena Bernardo / Jorge Sampaio / Marta Borges

2035 O convento de Nossa Senhora da Esperança de Ponta Delgada: o contributo da arqueologia para o conhecimento de um monumento identitário João Gonçalves Araújo / N’Zinga Oliveira

2047 Arqueologia na ilha do Corvo... em busca da capela de Nossa Senhora do Rosário Tânia Manuel Casimiro / José Luís Neto / Luís Borges / Pedro Parreira

2059 Perdidos à vista da Costa. Trabalhos arqueológicos subaquáticos na Barra do Tejo Jorge Freire / José Bettencourt / Augusto Salgado

2071 Arqueologia marítima em Cabo Verde: enquadramento e primeiros resultados do projecto CONCHA

José Bettencourt / Adilson Dias / Carlos Lima / Christelle Chouzenoux / Cristóvão Fonseca / Dúnia Pereira / Gonçalo Lopes / Inês Coelho / Jaylson Monteiro / José Lima / Maria Eugénia Alves / Patrícia Carvalho / Tiago Silva

2085 Trabalhos arqueológicos na Cidade Velha (Ribeira Grande de Santiago, Cabo Verde): reflexões sobre um projecto de investigação e divulgação patrimonial André Teixeira / Jaylson Monteiro / Mariana Mateus / Nireide Tavares / Cristovão Fonseca / Gonçalo C. Lopes / Joana Bento Torres / Dúnia Pereira / André Bargão / Aurélie Mayer / Bruno Zélie / Carlos Lima / Christelle Chouzenoux / Inês Henriques / Inês Pinto Coelho / José Lima / Patrícia Carvalho / Tiago Silva

2103 A antiga fortificação de Quelba / Khor Kalba (E.A.U.). Resultados de quatro campanhas de escavações, problemáticas e perspectivas futuras Rui Carita / Rosa Varela Gomes / Mário Varela Gomes / Kamyar Kamyad

2123 Colónias para homens novos: arqueologia da colonização agrária fascista no noroeste ibérico Xurxo Ayán Vila / José Mạ . Señorán Martín 


\title{
UM CONJUNTO CERÂMICO MEDIEVAL FORA DE PORTAS: UM BREVE TESTEMUNHO AVEIRENSE
}

\author{
Susana Temudo ${ }^{1}$
}

\begin{abstract}
RESUMO
A realização de uma intervenção arqueológica de diagnóstico e de salvaguarda patrimonial, na avenida de Santa Joana, Aveiro, no biénio de 2017-18, permitiu a constituição de um acervo cerâmico até ao momento sem paralelos conhecidos na cidade.

Proveniente de depósitos de aterro antrópicos e de estruturas em negativo, o conjunto cerâmico insere-se numa linha temporal estremada entre o século IX e o séc. XIII, constituído por vasilhames de caráter doméstico como panelas, alguidares, jarros, bilhas, potes e caçoilas. Fragmentos com pastas resultantes de diferentes fabricos e gramáticas decorativas plásticas em cordão, puncionadas ou incisas.
\end{abstract}

Palavras-chave: Aveiro, Cerâmica, Medieval, Séc. IX-XIII.

\begin{abstract}
The realization of an archaeological intervention of diagnosis and heritage safeguard, in Santa Joana avenue, Aveiro, in the biennium of 2017-18, allowed the establishment of a ceramic collection so far without known parallels in the city.

From anthropic landfill deposits and negative structures, the ceramic collection is part of a storm line between the 9 th and the 13th century. It consists of domestic pottery such as pans, pots, bowls and jars. Fragments with pastes resulting from different manufactures and plastic decorative grammars like punched and structed motifs. Keywords: Aveiro, Pottery, Medieval, IX-XIII Century.
\end{abstract}

\section{BREVE ENQUADRAMENTO}

Os trabalhos arqueológicos desenrolaram-se no âmbito da construção de um empreendimento privado, na avenida de Santa Joana - Aveiro, num lote, à data dos trabalhos, sem qualquer tipo de edificação visível, justificando-se a intervenção pela sua inscrição na Zona de Proteção do Monumento de Interesse Público - Edifício Testa \& Amadores.

Pertencente a atual união de freguesias da Glória e Vera Cruz, a área assume-se de grande sensibilidade arqueológica, pelo que foi objetivo a deteção de vestígios arqueológicos, com a consequente minimização de impactos e salvaguarda dos elementos patrimoniais/arqueológicos pelo registo. Nesse sentido a escavação teve em consideração a sua área de implantação conjugada pela sua proximidade para com antiga linha de muralha, ainda que do lado exterior a esta mas no enfiamento da antiga porta da vila que permitia o acesso ao quarteirão do bairro dos oleiros e ao núcleo populacional em torno da antiga igreja do Espírito Santo, sede freguesia em 1572, demolida entre 1858 e 1875 (Curado, 2019, p. 9o). Não esquecendo o atual Museu da Princesa Santa Joana, também conhecido como o antigo mosteiro de Jesus.

Da intervenção resultou a constatação de uma ocupação do espaço desde o período medieval até aos nossos dias, com especial incidência nas centúrias seiscentista e setecentistas, apesar das interferências dos revolvimentos ocorridos na contemporaneidade. Assinalaram-se várias estruturas correlacionáveis com os níveis modernos e cadastráveis com a cartografia existente, os quais se sobrepuseram direta ou indiretamente sob os depósitos medievais e cuja temporalidade se posiciona entre os inícios do séc. XIV, recuando até ao séc. IX-X. Uni-

1. susanathemudo@gmail.com. 
dades estratigráficas assentes sobre o solo geológico em forma de aterro, por vezes cortadas por fossas detríticas, maioritariamente atribuíveis aos níveis de ocupação moderna ou então assinaláveis em estruturas em negativo como as fossas concheiro ${ }^{2}$ ou covachos de perfil côncavo (Figura 1). Desses estratos exumou-se um conjunto considerável de materiais composto por cerâmicas, numismas, líticos e fragmentos de tégula, assim como fauna mamalógica e malacológica.

\section{AVEIRO MEDIEVAL: APONTAMENTOS HISTÓRICOS VS DISCURSO ARQUEOLÓGICO}

A freguesia de Vera Cruz foi fundada a ro de Julho de 1572 pelo Bispo João Soares, atendendo ao crescimento populacional que se fez sentir nessa parte da cidade e atestado pelo livro de óbitos da freguesia de S. Miguel ${ }^{3}$ (Gonçalves, 1986, p.107). Justifica Jorge Arroteia (1999, p. 36) que a população ter-se-á expandido durante essa centúria face ao crescimento económico do burgo: "a população foi augmentando, chegando a transpor os limites que a apertavam, e dilatando-se para norte e para sul, formou arrabaldes cheios de boa casaria, que não tardaram a constituírem-se em novos bairros da vila" (Costa, 1930, p. 36).

O lote localiza-se exatamente na parte sul da cidade e fora da antiga zona de intramuros da cerca muralhada, nas imediações do atual largo da Fonte das 5 Bicas, local de implantação da igreja do Espírito Santo e na saída da porta de muralha que ligava à rua Direita, hoje rua dos Combatentes da Grande Guerra, portanto, junto de um dos principais eixos da rede urbana, no quarteirão fronteiro ao bairro das olarias (Figura 2).

Da análise da cartografia sabemos que o espaço onde se recolheu o espólio apresenta edifícios deduzíveis na cartografia de 1696 e evidenciadas com maior rigor na de 178o-81. Porém, a ocupação dos quarteirões em torno da igreja do Espírito Santo, de acordo com as parcas fontes históricas, as edificações serão

\footnotetext{
2. Estruturas em negativo de planta circular ou subcircular e de perfil concavo, escavadas no solo geológico ou cortando outros depósitos arqueológicos; preenchidas por conchas de bivalves (ameijoa, ostra, mexilhão ou berbigão).

3. Atualmente pertencente à união de freguesias da Glória-Vera Cruz.
}

anteriores, ainda que os trabalhos arqueológicos já executados apenas tenham registado ocupações de época moderna4. Segundo Rangel Quadros (2009, p. 137), apesar de não existir nenhuma documentação que ateste a fundação da igreja, sabe-se que D. Dinis terá mandado erguer vários templos sob esta invocação, descrevendo a de Aveiro onde "o arquitecto havido tido as suas pretensões a dar-lhe um estilo romano-bisantino (...) teria muito semelhança com os templos de S. Tiago e de S. Cristóvão da Cidade de Coimbra"; referindo mais adiante que no seu frontispício ostentava uma varanda sob o arco da entrada principal "e sobre esse arco havia um pequeno oculo redondo, envidraçado que dava luz ao interior da capela" (Idem, p. 138). Indícios que permitem aventurar uma edificação para o período balizado pelo estilo românico e consequentemente, contemporâneo à fundação da nacionalidade. As comparações com as supostas homólogas de Coimbra apontam para uma edificação no séc. XII. A igreja de S. Tiago, segundo Nogueira Gonçalves (1938, p.121), terá sido edificada no ano de 1183 . $\mathrm{O}$ que posiciona a data da sua fundação durante $o$ reinado de Fernando, o Magno, e consequentemente, a integra no arcebispado de Santiago de Compostela, ao qual pertenceu até 1183 (Viqueira, 1957, p.77). Com o crescimento urbano do arrabalde coimbrense, torna-se igreja paroquial e, por certo, terá sido por essa altura em que ocorre a primeira grande transformação arquitetónica, com a construção da matriz românica. Consta que terá sido erguida antes de 1206 - data da sua consagração (Borges, 1987, p. 88; Dias,1995, p. 56; Sacarrão,1999, p.4), uma vez que em 1119 tinha sido destruída pelo cerco de Ali Ibn Jusuf, e novamente afetada pelos ataques de 1139 e 1142, implicando, pois, a sua reconstrução em 1183 (Pereira, 1995, p. 254-55). A sua conterrânea, a de S. Cristovão ${ }^{5}$, apesar de ainda não haver consenso sobre a data de fundação, pelas características des-

\footnotetext{
4. Relembre-se que grande parte das intervenções arqueológicas ocorrem na figura do acompanhamento arqueológico. Ação que tem como intuito a observação e registo dos vestígios revelados pelas ações da obra e as quais nem sempre permitem visualizar a totalidade dos contextos arqueológicos, uma vez que os arqueólogos ficam sempre limitados à "cota de obra".

5. Igualmente demolida no séc. XIX para dar lugar a um teatro, reformulado posteriormente, resultando no atual teatro Sousa Bastos, sito no encontro da rua Joaquim António Aguiar com a rua das Esteirinhas.
} 
critas nas fontes documentais e iluminuras conhecidas, sabe-se que se insere dentro do estilo românico e que durante o tempo do Conde D. Henrique (1099-1108) já existia (Alarcão, 2008, p. 93).

A cidade de Aveiro é referida pela primeira vez num documento datado de 959, indicada pelo nome de "Alavarium in territorio Colimbrie (...) terras in alavarium et salinas(...)" (Oliveiros, 1984, p. 17), surgindo posteriormente em 1050 já com o nome de vila de Alaveiro, no inventário dos bens de Gonçalo Ibn Egas e de sua mulher D. Flâmula: "in illa marina costa sala tertia de Alaveiro" (Idem, p. 18), referindo António Gaspar que a zona central do burgo se posicionaria junto da antiga igreja de S. Miguel, demolida em 1840 para dar lugar ao largo municipal, delimitado a sudeste pelo edifícios dos Paços de Concelho (Cruz, 2005, p. 19). Igreja que se posicionava ao fundo da antiga rua Direita. Ora, sabendo da existência de um pequeno aglomerado no séc. $\mathrm{X}$ no eixo central da vila, com ligação a outro espaço religioso, a igreja do Espírito Santo, acredita-se que os vestígios arqueológicos encontrados possam estar relacionados com a presença de uma pequena mancha urbana posicionada numa área correlacionável com o núcleo populacional existente nas imediações da igreja do Espírito Santo e que com a construção da muralha no séc. XIV, ficou fora de "muros". Um elemento arquitetónico que somente veio assumir com maior premência a importância da cidade no contexto económico nacional, quebrando assim o caracter senhorial que ostentava desde os tempos da reconquista, apesar de ligeiramente atenuado com a elevação a vila por D. Dinis, responsável pela primeira cerca, após a sua recuperação para a coroa em 1306 (Silva, 1991, p. 13). Refira-se que terá sido no âmbito desta elevação que a igreja do Espírito Santo terá sofrido reformulações a julgar pela presença do seu escudo real no arco cruzeiro (Quadros, 2009, p. 138). Indício da importância que este templo teria no núcleo urbano da cidade.

$\mathrm{O}$ registo arqueológico aponta para um assentamento contemporâneo do burgo inicial, ainda que não se tenham encontrado estruturas habitacionais. Uma população provavelmente ligada à exploração do sal e às atividades piscatórias. Entre o espolio assinalou-se alguns pesos de pesca em cerâmica de pasta cinza e outros objetos líticos que poderão estar relacionados com este ofício, o que permite assegurar que se trata de uma povoação autóctone ou com residência sazonal. Possibilidade que poderá justifi- car a ausência de estruturas fixas e indiciando a utilização de elementos construtivos de pouca durabilidade, os quais poderão explicar a presença das valas, buracos de poste e os covachos (Figura 3). Contudo, também poderão corresponder a áreas de descarte, nomeadamente as fossas e covachos (deixando em aberto a interpretação das valas), posicionando-se os espaços da habitação na zona contígua à parcela, sita a sudeste e assim orientados para o largo das 5 Bicas, local que se crê central deste núcleo.

A questão relativa aos materiais de construção é referida na documentação, sendo os mais viáveis e de fácil acesso, segundo a autora Maria Violante Silva (1997), a madeira, utilizada na armação dos telhados e na edificação das próprias casas - talvez nos ditos "pardieiros"; a pedra, com predomínio do calcário, oriundo do Eixo; o barro e o seixo/calhau rolado, material em abundância na zona, procedentes do mar. Para além destes, há menção ao tijolo seco ao sol e depois cozido no forno. Um material muito utilizado em toda a cidade, havendo inclusive menção que o mesmo era utilizado em construções notáveis, como no Mosteiro de Jesus.

Dos elementos elencados pela autora, o registo arqueológico identificou a presença de seixos conjuntamente com pedra granítica. Aliás refira-se que a presença do granito está associada aos níveis de ocupação medieval, apesar dessa pedra também ter surgido igualmente nas edificações do período moderno, conjugadas com outras em calcário e arenitos, tendo-se interpretado como reaproveitamentos das estruturas preexistentes, pois refira-se que a presença desta pedra nas construções modernas na cidade não é comum. Por norma os aparelhos construtivos modernos caracterizam-se pela presença dos arenitos vermelhos, seixos rolados de grande calibre, xisto, tijolos, alguns da tipologia rabo de andorinha, telha e fragmentos de cerâmica vermelha, nomeadamente as formas de açúcar; envoltos em argamassas pobres em cal e de cor castanha ou amarelada. Acrescente-se ainda que se registou a presença de fragmentos de tégula de pasta laranja em alguns contextos. Indicador da presença de construções. Daí acreditar-se que o espaço habitacional situar-se-ia nas imediações da área escavada ou então, terem sido desmontadas e a reaproveitadas. 


\section{O CONJUNTO DAS CERÂMICAS} DE PASTA CINZENTA DE AVEIRO...

Apesar da oportunidade em observar um conjunto de fragmentos extenso, permitindo uma sucessão cronológica de ocupação e de destruição/abandono definido pela estratigrafia do sítio, é consciência de que o estudo deste acervo em particular, ainda não se encontra concluído, uma vez que falta completa-lo com outros elementos e realizar um estudo comparativo e contextual mais aprofundado. No entanto, acredita-se que é importante dar a conhecer algumas dessas peças, lançando Aveiro para a discussão que até ao momento tem sido mantida à parte nas cronologias medievais mais recuadas. A presença deste conjunto permite repensar a ocupação da cidade e pela primeira vez, o testemunho arqueológico parece confirmar o referido pelas fontes históricas.

Os materiais surgem em contextos com pouca expressividade estratigráfica quando comparados com os das cronologias anteriores, associados a níveis de depósito antrópico maioritariamente de aterro, existindo, porém, alguns de níveis selados como as fossas concheiro e as valas. Os objetos aqui apresentados compõem uma amostra selecionada desses estratos, em concreto das camadas [204], [506] e dos concheiros [504], [518], [547] e [557]; encontrando-se este último selado por uma unidade datada por um dinheiro de D. Dinis. Portanto atribuível ao séc. XII-XIII.

Deste conjunto constatou-se a presença de artefactos de carácter doméstico, pertencentes a diferentes universos. Identificaram-se fragmentos de louça associada ao armazenamento e transporte: potes; louça de cozinha: alguidares e panelas; e louça de mesa: bilhas e taças. Fragmentos que pressupõem a ocupação deste espaço. Curiosamente os fragmentos não se encontram rolados ou com indícios de desgaste, denunciando, pelo contrário, um bom estado de conservação e dimensões consideráveis, permitindo várias colagens. Outro aspeto interessante é o facto de alguns deles apresentarem vestígios de combustão, atribuindo às suas superfícies externas uma imagem ainda mais enegrecida (Figura 5).

\subsection{Características do fabrico}

As pastas das cerâmicas foram observadas superficialmente e havendo a consciência de que a análise ainda se encontra por concluir, é certo que se destacam dois grandes grupos dentro das pastas cinzentas. Uma diferença que poder-se-á justificar por pertencerem a sítios produtivos e/ou ambientes temporais diferentes dentro da medievalidade.

Os fragmentos foram feitos a torno e denunciam uma cozedura redutora.

\section{Tipo 1}

O primeiro grupo correspondente ao de pastas mais claras, homogéneas, de superfícies alisadas e bastantes micáceas, provendo uma imagem metálica provocada pelo reflexo das micas. Estas estão presentes nos fragmentos que se julgam ser mais recentes, ou seja, atribuíveis aos níveis do séc. XII/XIII, como é o caso do alguidar carenado presente na estampa 4, pertencente à u.e. [557]; e as asas de bilha decoradas constantes na Figura 4.

\section{Tipo 2}

Grupo com maior representatividade e composto pelos fragmentos de cor cinza acastanhada; pastas não tão compactas como o primeiro, homogéneas, pouco alisadas e com desengordurantes bem destacados, como quartzos e micas, entre outros; contendo alguns fragmentos, sobretudo os alguidares de base em disco alargado, mica dourada. Curiosamente, são estes que surgem nos contextos cronológicos mais recuados - séc. IX-X, e que no caso aqui apresentado corresponde aos alguidares com decoração plástica em cordão da estampa 4, contemporâneos dos potes da estampa 1 .

\subsection{As formas}

Para a sua nomenclatura foi seguida a terminologia da cerâmica medieval sugerida por Torres et alli (1997). As formas identificadas encontram-se documentadas na região norte e centro, apresentando os exemplares de Santa Joana paralelos em Conimbriga, Coimbra, Santa Olaia (Figueira da Foz), Casal da Malafaia e Castelo de Arouca, Viseu e Crestuma (Vila Nova de Gaia) (Mann; Tente, 2012; Nazaré, 2012). Os potes mostram quase sempre a mesma morfologia, mas variedade quanto ao tamanho, com oscilações entre os $14 \mathrm{~cm}$ e os $16 \mathrm{~cm}$ de diâmetro; bordos boleados ou ligeiramente extrovertidos e de lábios com um leve ressalto (Estampa 1). Não se conseguiu assinalar nenhum perfil completo, mas pela dimensão e orientação das paredes é percetível que seriam pouco espessas, perfazendo corpos ovoides estrangulados no colo e base plana.

As panelas presentes na estampa 2 inserem-se plenamente nos contextos domésticos do séc. X-XI. Re- 
presentam as formas com maior expressividade no conjunto com bordos extrovertidos, lábios arredondados, colos côncavos e corpos globulares de base plana com asas de perfil oval ou plano, com ou sem decoração puncionada. Dentro das panelas de pasta cinza, inseríveis no grupo 2, existem também exemplares de asa em rolo e paredes côncavas com caneluras.

Deste grupo destacou-se ainda a presença da panela de bordo reto e paredes com caneluras paralelas (Estampa 2, Figura 5). Uma forma que surge no mesmo contexto que um dos potes da estampa 1.

Os alguidares, a forma mais comum nos acervos cerâmicos pela sua multifuncionalidade, apresentam quase sempre a mesma tipologia. Formas troncocónicas, de paredes retas e oblíquas, com ou sem decoração em cordão digitado, tal como no lábio; de base em disco alargado e igualmente com ou sem decoração (Estampa 4).

As taças surgem como formas abertas de grande dimensão, com vários diâmetros, com variações entre os $15 \mathrm{~cm}$ e os $18 \mathrm{~cm}$. Corpos de paredes côncavas e bordos de diferentes tipologias (Estampa 3).

Por último, as bilhas (Figura 4), representadas pelas suas asas planas ou ligeiramete ovais, com uma decoração golpeada ou puncionada. Infelizmente desta forma não se obteve nenhum perfil completo, havendo, no entanto, a possibilidade de algumas colagens.

\section{CONSIDERAÇÕES FINAIS}

Das formas encontradas nesta intervenção e pela amostragem aqui exposta, conclui-se que não existe uma variedade muito grande quanto ao tipo de vasilhame. No entanto, assumem-se como um primeiro contributo para o estudo da cerâmica medieval de Aveiro, até ao momento desconhecida. Acredita-se que estas cerâmicas poderão ser fruto de uma produção local, talvez feitas no bairro dos oleiros e com as argilas de Aveiro. As denominadas margas cinzentas e que poderão corresponder às pastas pertencentes ao primeiro grupo. Porém, admite-se a igual possibilidade de haver peças de outros locais, como Coimbra, nomeadamente o grupo das pastas acastanhadas, apesar dos alguidares de micas douradas poderem ser fragmentos fruto de produções mais a norte. Atualmente os dados ainda são muito escassos e parcelares, não permitindo uma visão global sobre a sua distribuição na região, pelo que o que se apresenta deverá ser considerado como um ponto de partida de um estudo que ainda se quer mais aprofundado.

\section{BIBLIOGRAFIA}

AMORIM, Inês (1996) - Aveiro e sua provedoria no séc. XVIII (169o-1814): Estudo económico de um espaço histórico; Dissertação de Doutoramento apresentada à Faculdade de Letras da Universidade do Porto; Coimbra: Ed. Comissão de Coordenação da Região Centro.

ARROTEIA, Jorge Carvalho (1999) - Aveiro: aspectos Geográficos e do Desenvolvimento Urbano; Aveiro: Universidade de Aveiro.

BARREIRA, Manuel (2001) - As Muralhas da Vila de Aveiro em 1692 - Segundo o Tombo da Casa de Aveiro, Patrimónios n. ${ }^{1} 12001$, Abril 2001, ano XXII, 2ª série.

COSTA, A. B (1930) - Diccionário Chronográphico de Portugal continental e insular; XII vols; Vila do Conde: Typographia Privativa do Diccionário Chronográphico.

GASPAR, João Gonçalves (1988) - Porquê "Vera-Cruz" na cidade de Aveiro in Boletim Municipal de Aveiro, Ano XVIII, n.. 36, pág. 95-109.

GASPAR, Mons. João Gonçalves (1997) - Aveiro na História, Aveiro.

GONÇALVES, António Nogueira (1986) - Inventário Artístico de Portugal: Distrito de Aveiro, Lisboa.

GONÇALVES, A. Nogueira (1938) - Novas hipóteses acerca dos canteiros medievais de Coimbra, Coimbra: Gráfica de Coimbra Almedina.

MANN, Adrian; TENTE, Catarina (2012) - Estudos de cerâmica medieval: o norte e centro de Portugal - séculos XI e XII; Lisboa: Instituto de Estudos Medievais.

NAZARÉ, Maria João (2012) - Cerâmicas Medievais de Santa Olaia (Figueira da Foz) depositadas no Museu Municipal Dr. Santos Rocha; Dissertação de Mestrado em Arqueologia e Território; Coimbra: Faculdade de Letras.

NEVES, Amaro; FERREIRA, Delfim dos Santos Bismarck Álvares (2009) - História de Aveiro: sínteses e perspectivas, Aveiro.

PEREIRA, Paulo (dir.) (1995) - História da Arte em Portuguesa, vol I, $1^{\mathrm{a}}$ edição, Lisboa.

OLIVEIROS, Albertina Valentim (1984) - Aveiro no séc. XV in Boletim Municipal de Aveiro, n. $\stackrel{\circ}{4}$, Ano II, Aveiro: Câmara Municipal de Aveiro.

OUDINOT, José Rangel (2009) - Quadros - Aveiro. apontamentos históricos; CMA, Aveiro.

SACARRÃO, Carolina; PIMENTA, Olga; MESQUITA, Paula(1999) - A Igreja de S. Tiago de Coimbra, trabalho apresentado na disciplina de História da Arquitectura Clássica e Medieval, Lic. Arquitectura, Universidade de Coimbra, Coimbra.

SILVA, Cristina (1999) - Aveiro: território e cidade, Arqueo- logia de uma forma urbana; Dissertação de seminário da 
Licenciatura em Arqueologia; Faculdade de Ciências e Tecnologia da Universidade de Coimbra, Coimbra.

SILVA, Maria J. (1997) - Aveiro Medieval; Aveiro: Câmara Municipal de Aveiro.

VIQUEIRA, José M. (1957) - Coimbra: impressiones y notas de un itinerário, Coimbra Editora Limitada, Coimbra.

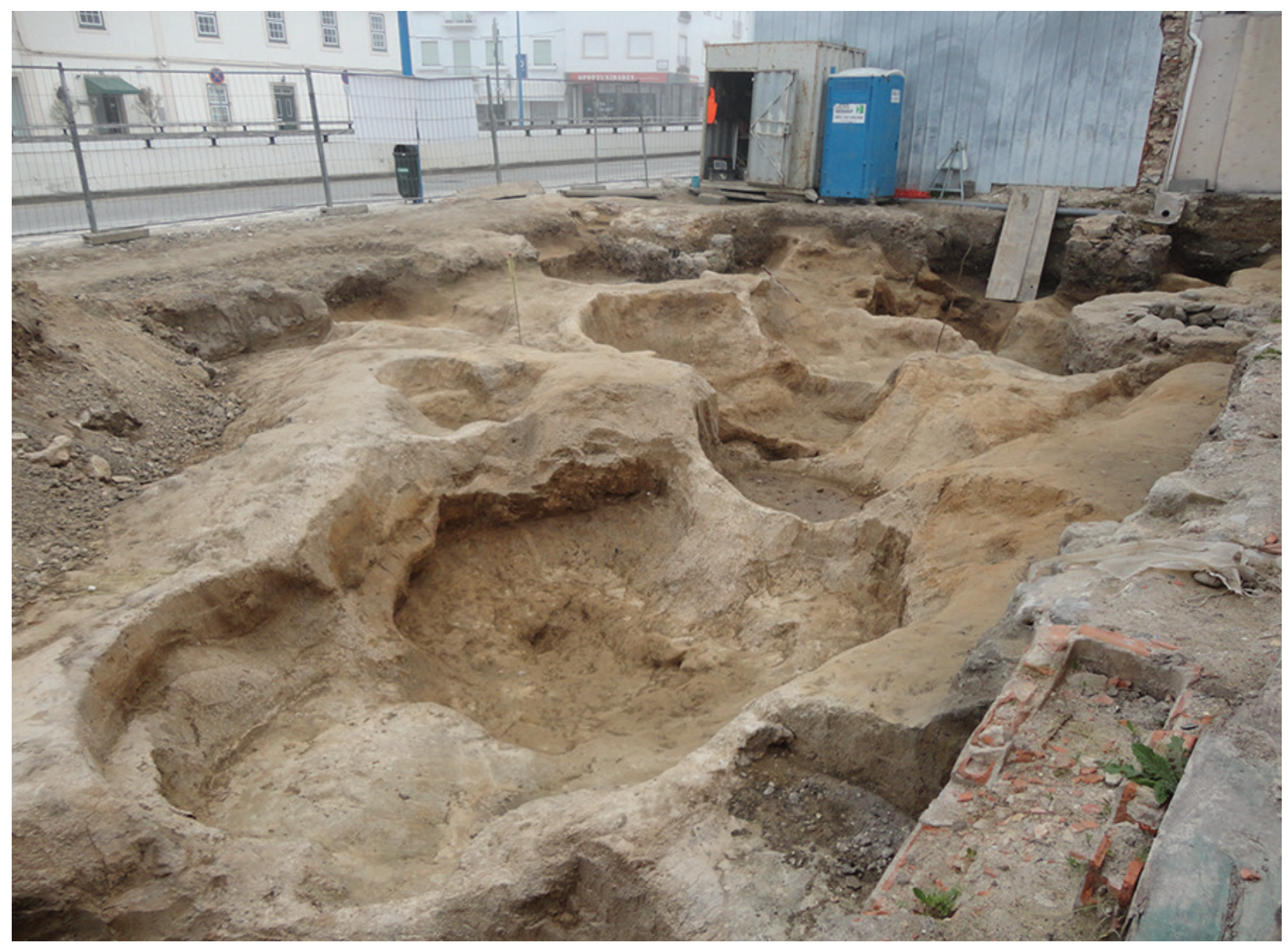

Figura 1 - Vista geral da área da escavação: plano final. 


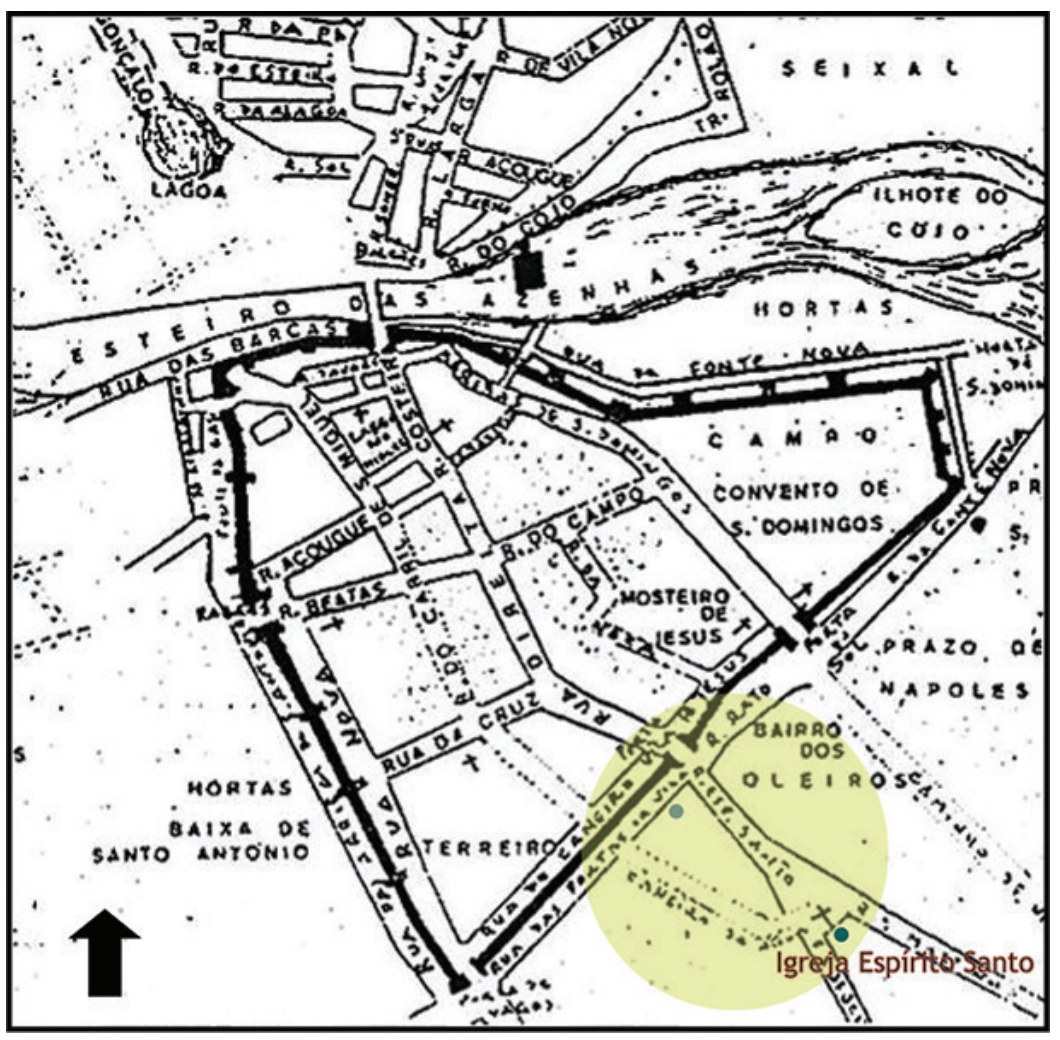

Figura 2 - Excerto do mapa da cidade datado de 1696 com a localização da intervenção e da Igreja do Espírito Santo.

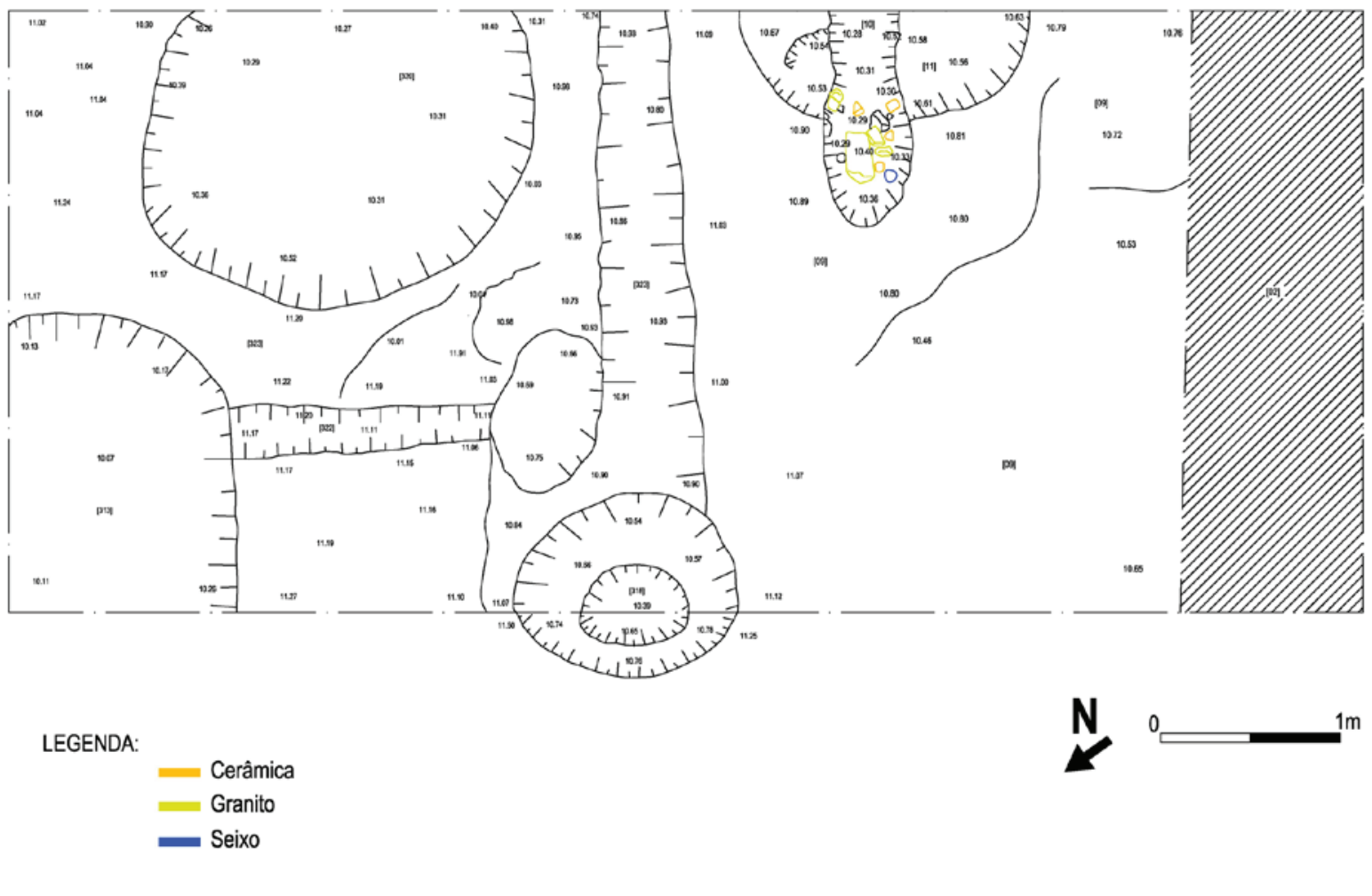

Figura 3 - Planta das fossas e valas. 


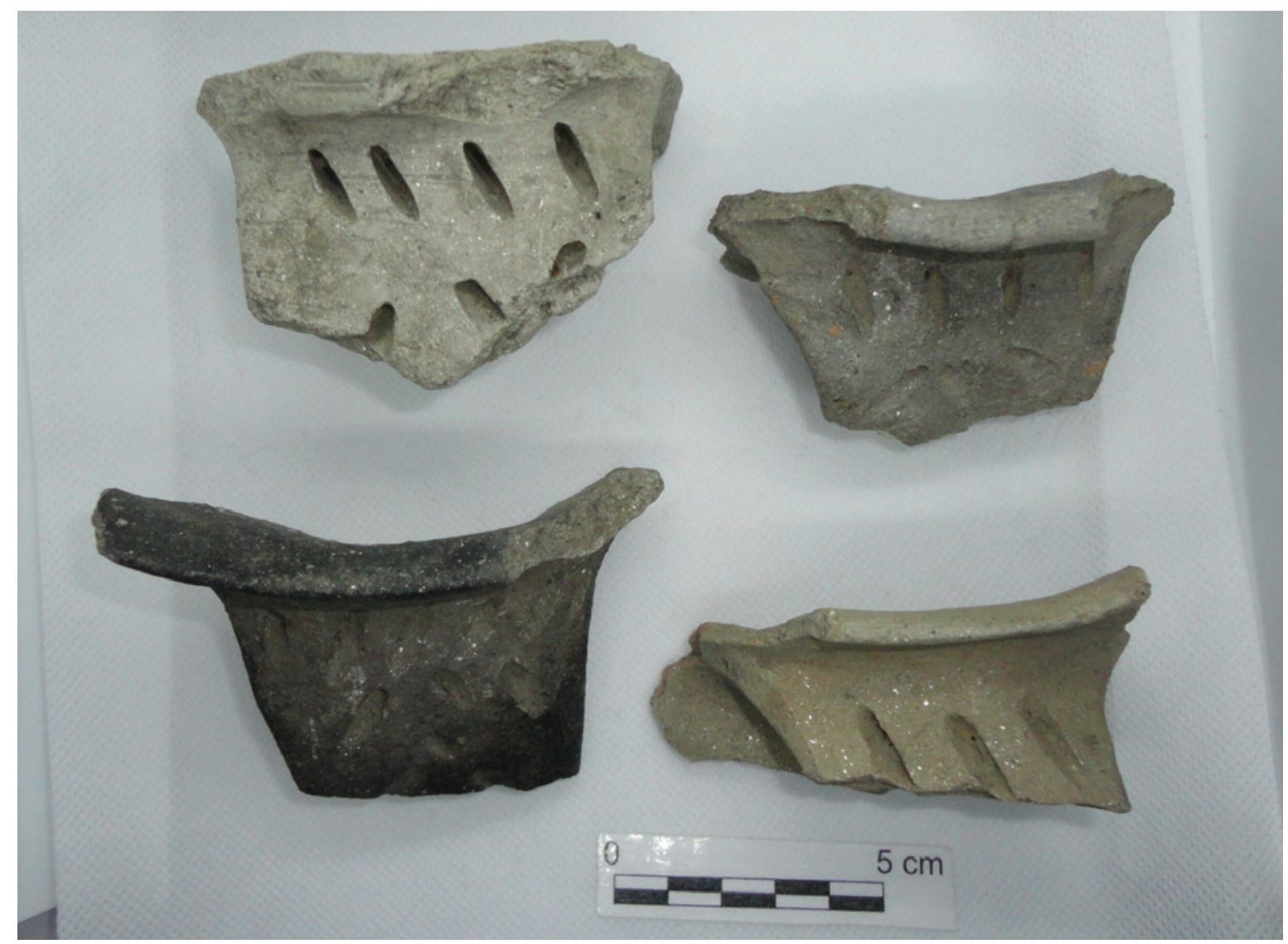

Figura 4-Asas de bilhas com decoração.

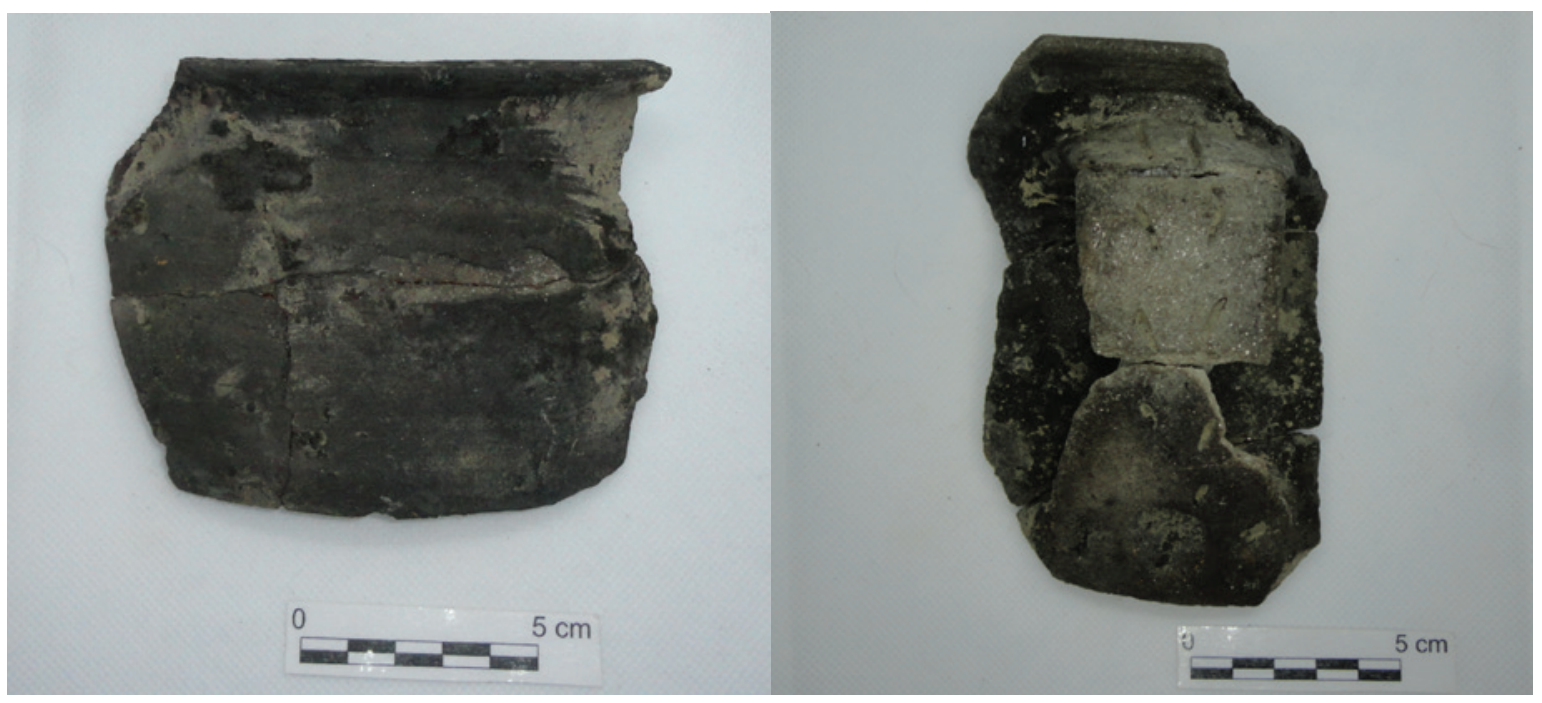

Figura 5-Panelas. 

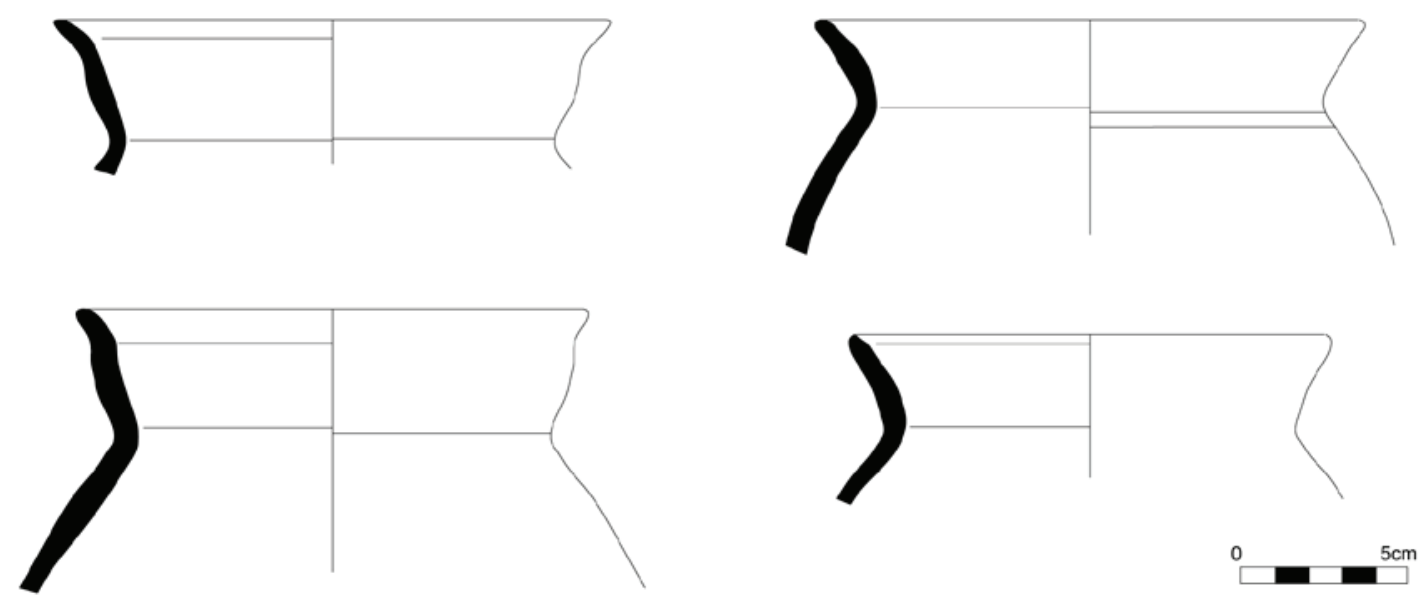

Estampa 1 - Potes.
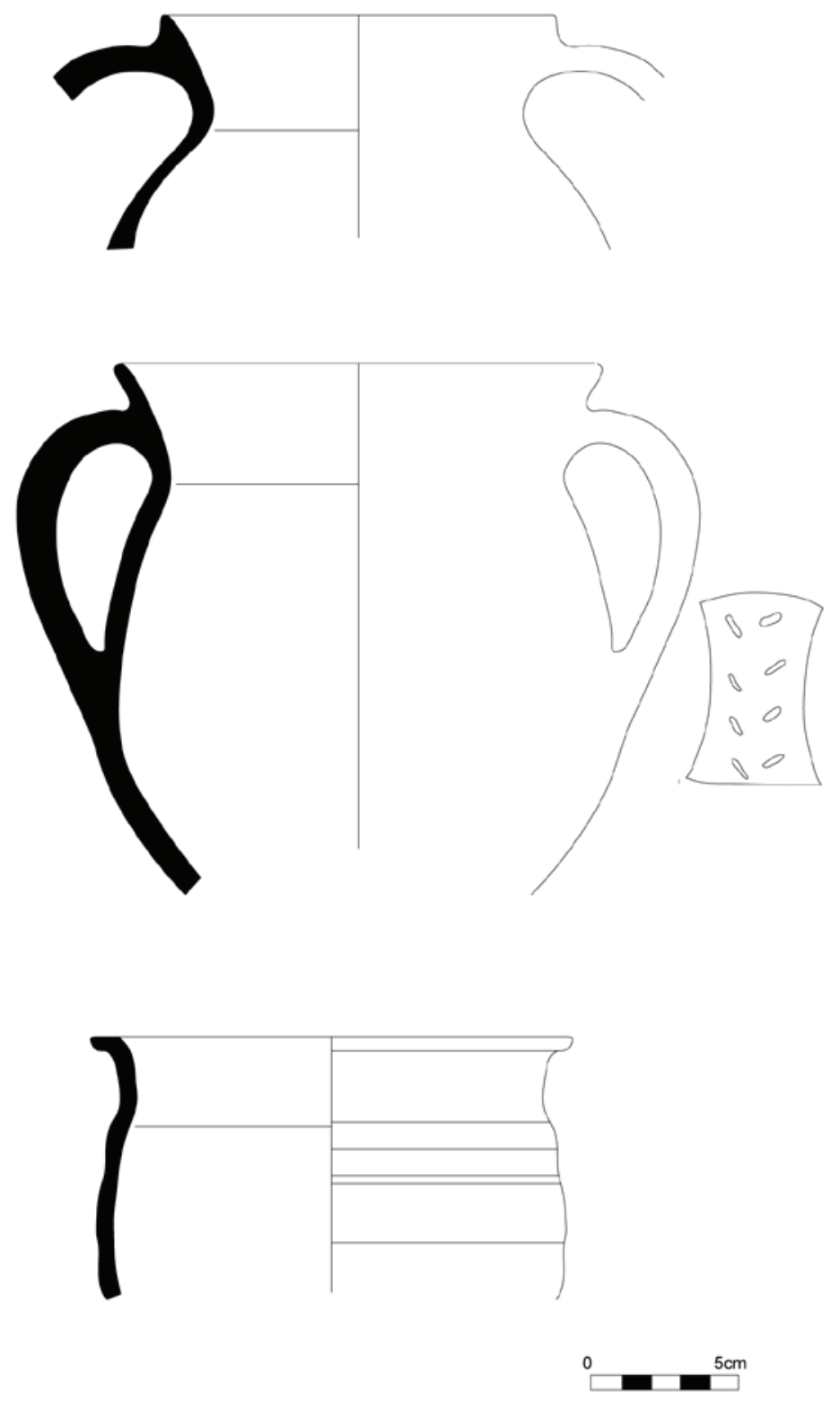

Estampa 2 - Panelas.

1649 Arqueologia em Portugal / 2020 - Estado da Questão 


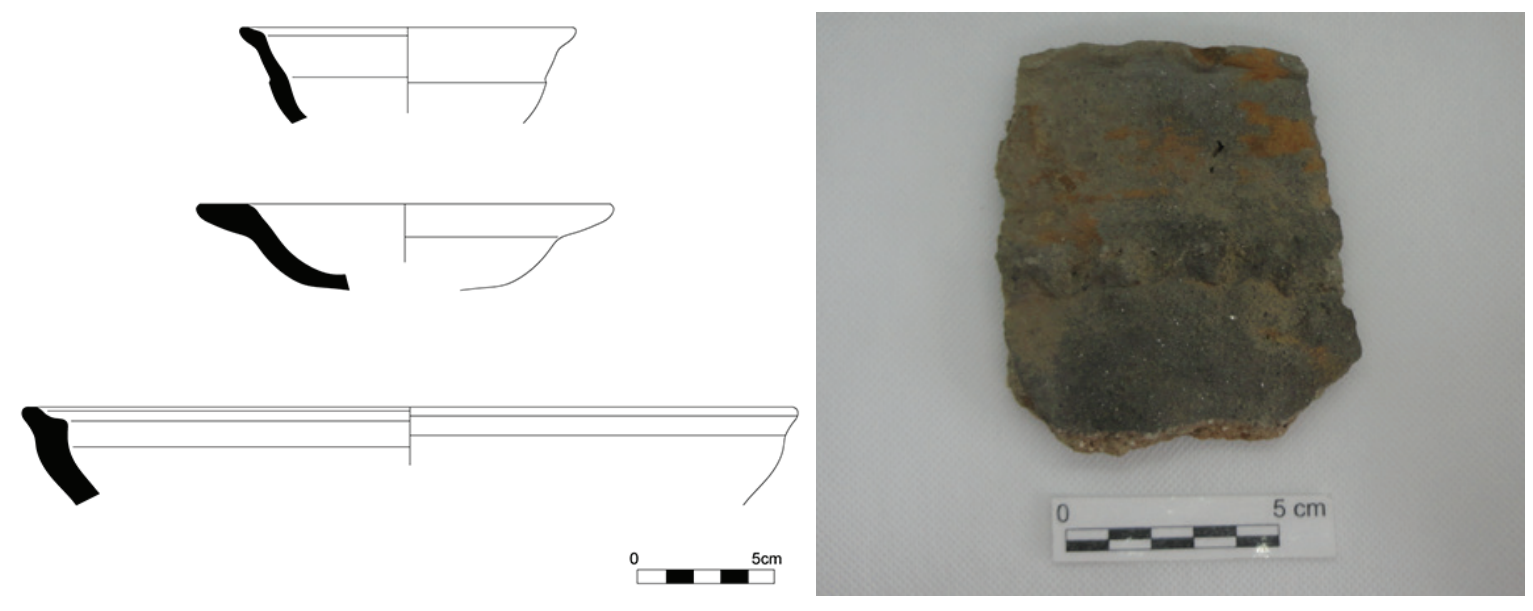

Estampa 3 - Taças. A fotografia é de um alguidar.
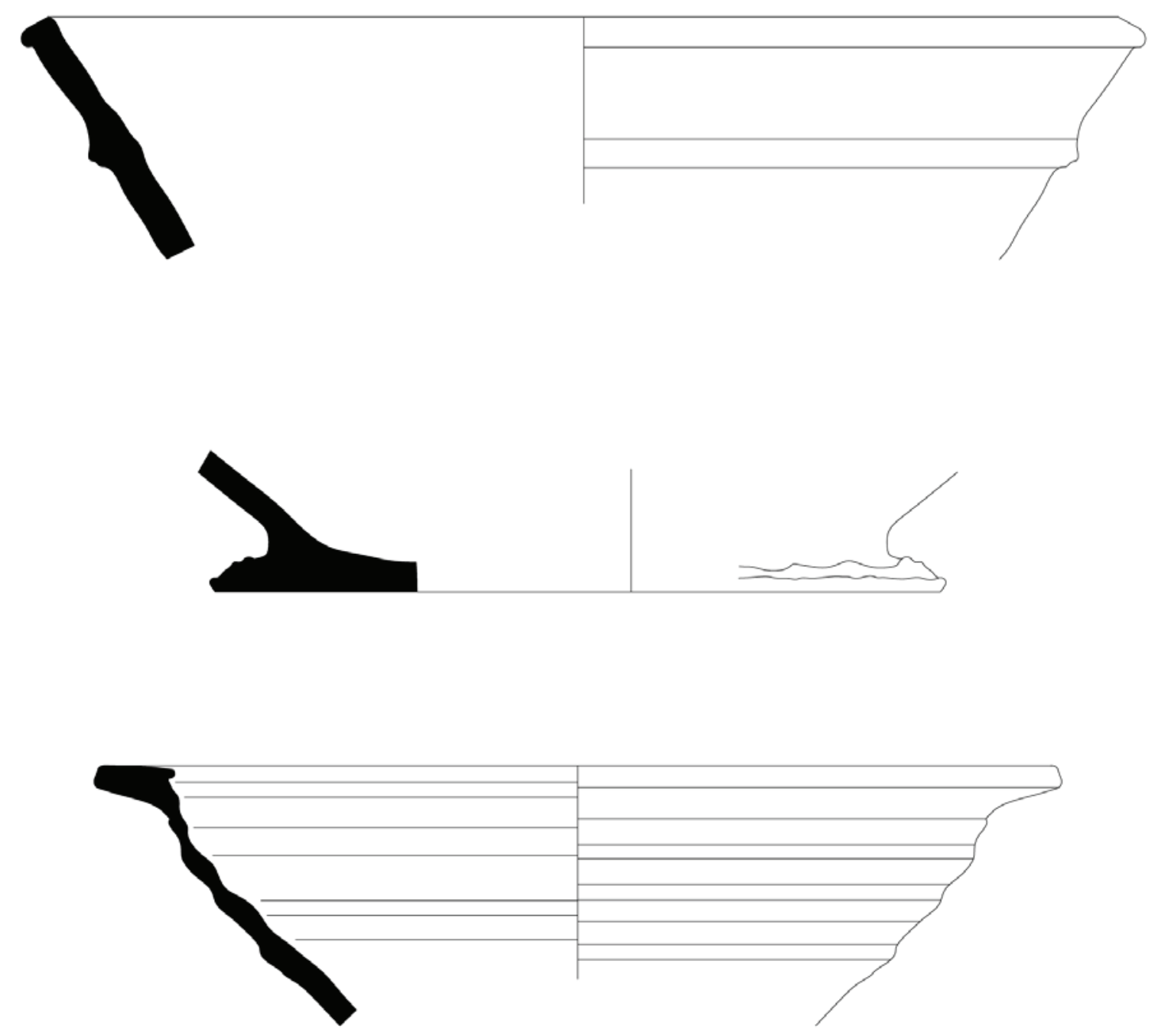

\begin{tabular}{ll}
$0 \quad 5 \mathrm{~cm}$ \\
\hline$\square$ & \\
\hline
\end{tabular} 



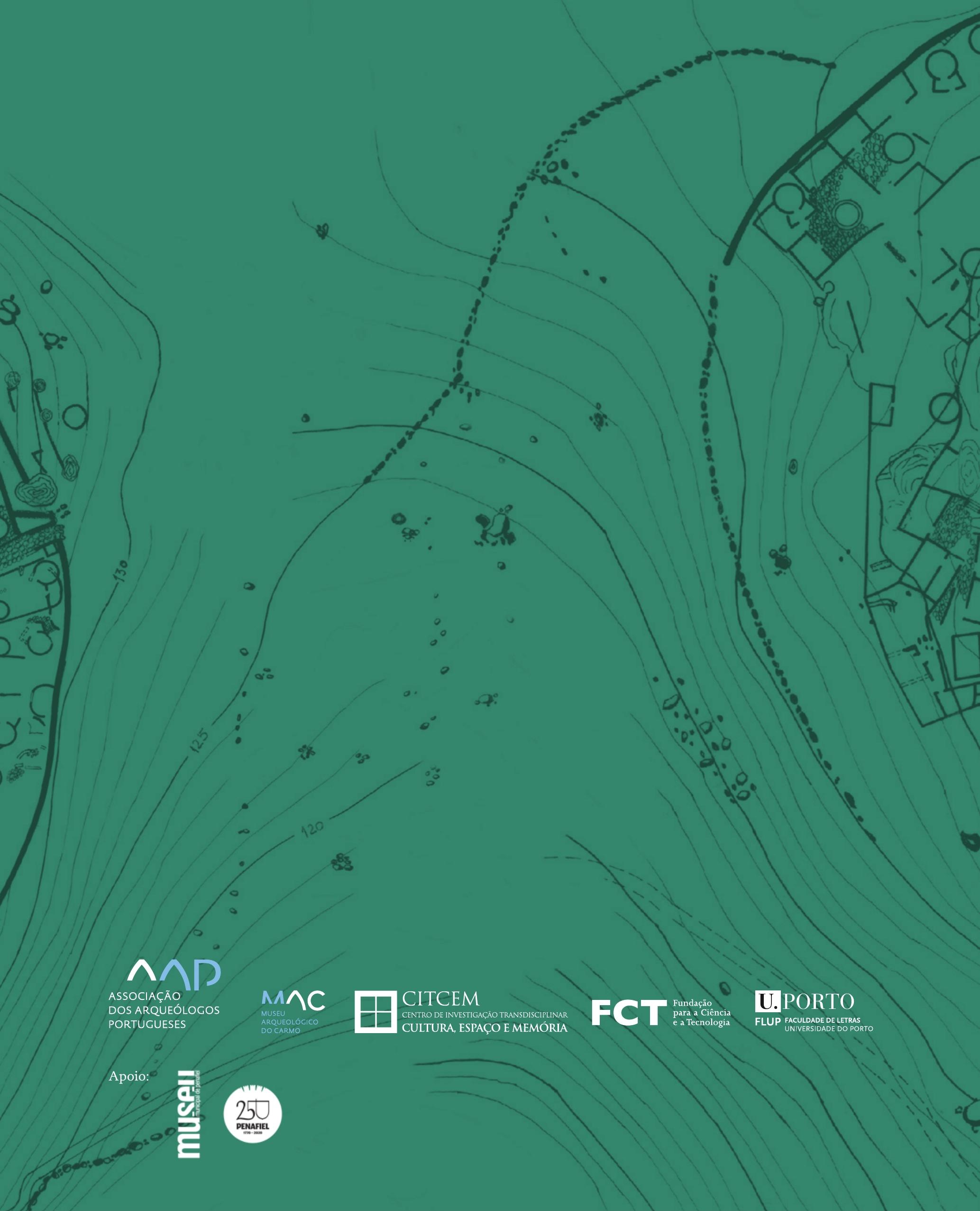

